\title{
Where Are All the Welfare Queens? Negotiating the Conditions of Wageless Life in Contemporary American Film
}

\section{Abstract}

The cultural treatment of wagelessness and welfare as its potential relief serves as a potent example of how popular culture has long functioned as a site at which American society articulates and negotiates its anxieties. Observing a recent departure from the figure of the "welfare queen" as the privileged site at which anxieties related to welfare are organized, and linking this change to the neoliberal transformations of welfare in the United States introduced by the 1996 reform, this paper adopts a Foucauldian approach to the issue of government in order to set the ground for an analysis of contemporary films which negotiate the conditions of wageless life in what has often been termed a post-welfare society. Looking at Beasts of the Southern Wild and The Florida Project as illustrative of a broader representational trend, this paper examines the role of popular culture in negotiating social changes by exploring the ways in which the two films negotiate dominant discourses of personal responsibility and work opportunity through the newly emergent figure of the "surplus population."

Keywords: wageless life, welfare queen, welfare, film, popular culture, Foucault

Popular culture has long functioned as a site at which American society articulates and negotiates its anxieties over class politics, often left unspoken in public discourse, which they nonetheless govern. The cultural treatment of issues pertaining to worklessness and welfare as its potential relief serves as a potent example. In the United States, the notion of welfare as the recourse for the wageless has traditionally been framed by the discourse on dependency as a moral failing on 
behalf of the poor who eschew the norms of the dominant work ethic. Since the late 19th century, the anxieties produced by this perceived deviancy have coalesced into the figure of a poor single mother. Each of its particular articulations inflected by contemporary socio-political concerns, this figure found its most beleaguered personification in the delinquent Reagan-era "welfare queen." Even though the "welfare queen" is still occasionally invoked both in public discourse and in popular culture, a shift from this figure as the typical embodiment of the "culture of dependency" can be detected in 21st-century representations of what Michael Denning (2010) has termed "wageless life." Situating the discussion of this trend in the context of neoliberal transformations of welfare in the United States, epitomized by the 1996 Personal Responsibility and Work Opportunity Reconciliation Act, this paper ventures to explore the ways in which several American films made over the past decade register and negotiate social changes effected at the level of public policy in the domain of welfare. It aims to do so by adopting a Foucauldian approach to the issue of government ${ }^{1]}$ in order to arrive at an analysis which sets the ground for understanding the representational choices which negotiate the narrative of dependency in what has often been termed a post-welfare society.

\section{The Birth of the "Welfare Queen"}

An overview of the history of welfare in the United States "reveals the many ways in which recipients have become politicized in relation to work-ethic discourses." (Weeks 80 ) The notion of welfare as the recourse for the workless has traditionally been framed by the discourse of dependency, informed by the normalization of wage labor in the 19th century and fueled by the faulty assumptions about the possibility of full employment in the growing postWWII economy. Outlining the historical processes whereby the notion of dependency became the key operative term of the US welfare state, Nancy Fraser and Linda Gordon note that as "wage labor became normative - and increasingly definitive of independence - it was precisely those excluded from wage labor who appeared to personify dependency." (316) Due to the fact of the gendered division of labor between feminized unpaid domestic work and masculinized wage labor, which was solidified through the aforementioned process of the normalization of wage labor with the rise of industrial capitalism (cf. Laslett and Brenner), new, gendered senses of dependency emerged and 
bore significantly on the development of welfare policy. As Mimi Abramovitz notes, the welfare policy in the United States has been informed by its commitment both to the work ethic and to the family ethic which "articulates and rationalizes the terms of the gender division of labor" (37), which set the ground for a two-track welfare system. On the one hand, "programs like unemployment and old age insurance offered aid without stigma or supervision and hence without dependency." (Fraser and Gordon 321) On the other hand, second-track programs, such as mothers' aid which "became the model not only for ADC but for all programs today called 'welfare'" (Gordon 37), rested upon the idea of finding those worthy of aid among many morally corrupt slackers and cheats through the employment of constant surveillance. Programs from both tracks referred to the family wage as the ideal, driving a gendered rift between the first-track programs, which came to be considered workers' entitlements, and "welfare" in the other sense of the word, which referred primarily "to the condition of poor women who maintain their families with neither a male breadwinner nor an adequate wage" (Fraser and Gordon 311). Welfare in the latter sense has typically been stigmatized and "always framed by the question, what should be done?" (Gordon $25)$, that is, the question of government. This question has become even more morally fraught with the inauguration of the New Deal which "intensified the dishonor of receiving help by consolidating a two-track welfare system." (Fraser and Gordon 321) Furthermore, the policies inaugurated by the New Deal, conventionally credited with introducing the modern welfare system, rested on the flawed assumption "that adequate employment would be available for all who were willing to work, and that unemployment (or underemployment) in a growing economy was therefore, in most cases, voluntary and willful" (Bertram 107). This belief, which understood worklessness as a choice illustrative of a characterological failing on behalf of the poor, considered to be unwilling to work, continued throughout the 20th century. "Welfare," in the sense of the second-track programs, has therefore come to be regarded not only as a gendered, but also as a morally stigmatized institution. Since the late 19th century, the anxieties which imbue the stigma of "welfare" in the latter sense have been culturally articulated through the figure of a poor single mother, who has become "enshrined as the quintessential welfare dependent." (Fraser and Gordon 311, emphasis in the original) Throughout the 20th century, this figure appeared in both public discourse and popular culture as a site which organized diffuse anxieties related to the issues of work and family, while 
concealing their social bases. Commonly portrayed as a young single mother who is unemployed and relies on the Aid to Families with Dependent Children (AFDC) or some other current form of state aid, not only did this figure fail to conform to both the dominant family form and hegemonic work ethic, but it also partook in "virtually every quality that has been coded historically as antithetical to independence." (Fraser and Gordon 327) In the 1970s, when "structural shifts in the labor market limited the ability of work and related welfare-state programs to deliver the levels of social protection they were designed to provide" (Bertram 99), cultural assumptions about the figure of a poor single mother coalesced into the discourse of the "welfare queen" as "a wily and fecund black matriarch who shirks employment, cheats the public aid bureaucracy, and spends her assistance check high on drugs and liquor, leaving her many children in appalling neglect" (Wacquant 84). The individualizing moralist drive behind this figure, compatible with a broader individualizing drift characteristic of the emergent American neoliberalism, allowed it to become "crystallized into a political symbol during the Reagan administration" (Hancock 36).[2] Obscuring the structural processes that informed the exclusions embodied in the figure of the "welfare queen," this individualizing discourse allowed policy to remain "focused on individual behavior modification" (Hancock 38) with welfare programs "recast to emphasize behavioral expectation and monitoring, incentives for right behavior, and penalties for noncompliance." (Soss et al. 2) Describing welfare programs in these terms, a number of authors (cf. Soss et al. 2011, Wacquant 2009) draw attention to neoliberal paternalism as the dominant mode of poverty governance and describe its punitive techniques in ways that allows us to consider the "welfare queen" as Foucault's "delinquent." The punitive technique which finds its correlative in the delinquent relies on "a biographical knowledge and a technique for correcting individual lives" (Foucault, Discipline and Punish 252) so that the delinquent "is not only the author of his acts (the author responsible in terms of certain criteria of free, conscious will), but is linked to his offence by a whole bundle of complex threads (instincts, drives, tendencies, character)." (Discipline and Punish 253) The "welfare queen" is not characterized so much by the act of receiving welfare or even by relying on it for subsistence instead of working, as by her entire deviant life, her case history. What is punished is not the act, but the person, a figure.

\section{The End of Welfare (Queens)}


However, as prominent as it was until the 2000s, this particular figure appears to be less common in contemporary cultural representations of welfare "dependency" or, to be more precise, wageless life. A different figure, which cannot be understood solely in terms of disciplinary power, seems to be emerging in its place, calling for a reconsideration of explanatory models which view the welfare system in the United States as a disciplinary regime relying solely on punitive techniques to uphold and enforce the norm of wage labor. A brief look at the changes in the US welfare policy at the end of the 20th century give us some clue as to why the "welfare queen" no longer functions as the privileged cultural correlative of the dominant forms of political reason. The 1996 Personal Responsibility and Work Opportunity Reconciliation Act introduced a number of significant changes into the US welfare policy. Poor families' entitlement to income support was virtually abolished through the introduction of the Temporary Assistance for Needy Families (TANF) in place of AFDC since this new policy forbade cash payments and other benefits for families with a member who had received aid as an adult for five years, as well as for unmarried teenage parents who live on their own with their children. Furthermore, the Act introduced cuts in food stamps and children nutrition programs. Finally, the most prominent novelty introduced was the requirement that adults who receive TANF should work after being in the program for two years, which is why this program has been dubbed "workfare." However, what is perhaps even more interesting than these measures themselves is the way that they were framed and rationalized in public discourse. The Act was supposedly intended to fight the epidemic of teenage motherhood by advocating "personal responsibility" as an alternative to the irresponsible dependency on welfare: "[T]his bill takes a step in the right direction in helping reduce the rising illegitimacy rates by providing funds for abstinence education, and by allowing states the option of denying benefits to welfare recipients who already have children living on the public dole." (Senate Debate and Floor Vote, Congressional Record, 1996: S9387, in Hancock 47) As it can be gleaned from this excerpt from congressional discussions on the topic, policy makers relied on statistical methods and departed from the mode of disciplinary surveillance in order to observe the phenomena of interest to them at the level of population and devise methods to delimit them, not eradicate them. Government was no longer

a matter of taking the individual at the level of individuality but, on the contrary, of using overall mechanisms and acting in such a way as to achieve overall states of equilibration or regularity; ... 
a matter of taking control of life and the biological processes of man-as-species and of ensuring that they are not disciplined, but regularized. (Foucault, Society 246-47)

What came into focus instead of the beleaguered figure of the "welfare queen" to be eliminated were the "illegitimacy rates" to be reduced.

What is also of interest to us is the fact that the system was reorganized so as to ultimately reduce the number of recipients and the cost of welfare, even though little was done in the way of actually eliminating the undesirable phenomena. Not only was it unclear how the law should affect teenage pregnancy and birth rates, but "[n]ot a single measure in the law was aimed at improving the employment options and conditions faced by welfare recipients." ${ }^{[3]}$ (Wacquant 85-86) Nan Marie Astone reflected on this contradiction in an early commentary of the Act: "I am quite willing to predict that if the act is successful in reducing welfare costs, even if non-marital pregnancies and birth rates for young women remain the same, its supporters will regard it as a success." (414) Indeed, since the early 2000s, the supporters of the Act "have gloated over its evident 'success' by pointing to one and only one statistic (revealing of its singular objective): the spectacular decline in the number of recipients." (Wacquant 94, emphasis in the original) Meanwhile, the national poverty rate has remained virtually unchanged and less than 60 per cent of household heads leaving TANF had found employment by $2002^{4]}$ (cf. Hays 58-59). What is then interesting is the fact that the state has clearly turned to considering matters such as the rates of the phenomena they wish to repress, whether these phenomena can be modified through punishment, and what that punishment would cost, the comparative cost of allowing these phenomena to occur and repressing them ${ }^{[5]}$, that is, the questions which Foucault characterizes as typical of the apparatuses of security, which apply the same penal law as the juridical and the disciplinary mechanism, but develop their preventive measures and organize corrective punishment with the view of keeping an undesirable phenomenon "within socially and economically acceptable limits and around an average that will be considered as optimal for a given social functioning." (Security, Territory, Population 5) This marks somewhat of a shift from the demonization of the "welfare queen" as we are no longer dealing only with the disciplinary mechanism with the delinquent as its correlative but are also faced with the mechanisms typical of biopolitics, which take the population as the privileged object of their analyses (cf. Foucault, Society Must Be Defended 244-45). Instead 
of constantly overseeing and punishing non-compliance to the norm of wage labor, these mechanisms recognize the structural necessity of unemployment and rely on the market to compensate the fluctuations, rather than trying to prevent unemployment from occurring: in a way, "they involve the delimitation of phenomena within acceptable limits, rather than the imposition of a law that says no to them." (Foucault, Security, Territory, Population 66) This allows these apparatuses to think not in terms of disciplinary surveillance, which so many authors find crucial for the US welfare system, but in terms of government in which a part of the population will always be deviant. ${ }^{[6]}$

This means that their anxieties can no longer find adequate cultural expression in the figure of the "welfare queen" as the privileged form. Even though this figure still informs representations of wageless life to a certain extent, in so much as the welfare system remains punitive to a degree ${ }^{[7]}$ another figure seems to be emerging and taking the dominant place. How, then, can this figure be described? Based on Michael Denning's elaboration on the issue of representing wageless life, this deviant part of the population can be figured in Marxian terms as the relative surplus population, relying on Marx's account of "a population which is superfluous to capital's average requirements for its own valorization, and is therefore a surplus population." (782) This figure seems to be present in a number of recent films, such as, for instance, Chop Shop (2007), Winter's Bone (2009), Beasts of the Southern Wild (2012), American Honey (2016), and The Florida Project (2017). All of these films portray the situation of wageless life, described by Denning as "a situation of lack, the space of exclusion: the unemployed, the informal." (80, emphasis in the original) All of them represent this situation with a marked lack of reference to the discourse of dependency, subverting the dominant narrative of exclusion from wage labor and revealing that there is, in fact, nothing to depend on. Furthermore, the very fact of wagelessness itself belies the welfare-to-work narrative typical of the PRWORA, thus revealing "a lag between regulatory and administrative concepts, and actual social experiences and predicaments." (Walters 145) Considering "cinema (as a set of practices and activities, as well as a set of texts) as something which never ceases to intervene in society, and which participates in the maintenance, mutation, and subversion of systems of power" (Shiel 4) allows us to explore the ways in which that lag is registered in the sphere of popular culture, approaching the interpretation of society, economics and culture as part 
of "a whole and connected social material process" (Williams 140) in order to grasp the complexity of the ways in which the situation of wageless life is negotiated post-PRWORA.

\section{Wageless Life in Beasts of the Southern Wild and The Florida Project}

Considering the limited scope of this paper, it is perhaps most opportune to do so by focusing our attention on two of the films mentioned earlier. Looking at Beasts of the Southern Wild and The Florida Project as cultural articulations of the social conditions of wageless life at a specific historical moment, we can explore the ways in which each film negotiates "the cultural logic of personal responsibility" (Hays 216) through representational choices which either reiterate or subvert the dominant discourse, "transforming the current crisis of neoliberal excess and inequality into a crisis of welfare dependence." (Jensen 2) Representing the situation of wageless life through the figure of the surplus population, the two films share a number of similarities. Like the "welfare queen" before them, the figures of the surplus population are situated in the private sphere, traditionally gendered as feminine and stigmatized in opposition to the masculinized public sphere of waged work. This representational feminization of wageless life prompts both films to explore Denning's "situation of lack" and "the space of exclusion" (80) by turning their attention to the matters of sustenance and housing, as topics traditionally pertaining to the feminized domain of secondtrack welfare programs. However, if these two films may be said to follow the same representational trend in turning away from the delinquent figure of the "welfare queen," the negotiation of the discourse of dependency, which traditionally frames reliance on the welfare system in the sense that allowed for the birth of the figure of the "welfare queen," is where the two films differ significantly. Whereas Beasts of the Southern Wild romanticizes wageless life as a realm of freedom with Hushpuppy as an individual who achieves independence through a refusal of welfare and a celebration of personal responsibility, The Florida Project lays bare the conditions of wageless life and offers commentary on the structural processes which inform it in an era where there is quite simply no longer anything to depend on.

Both films reflect on wagelessness as a "situation of lack" through discussions of the characters' diets. However, whereas Beasts of the Southern Wild promotes the idea of selfsustenance through 
animal rearing, with the lack of food as an issue to be resolved through personal responsibility, The Florida Project explores contemporary alternatives to welfare programs aimed at securing food for the poor while commenting on their cost. As for everything else, characters in Beasts of the Southern Wild rely on nature for food: Hushpuppy and her father eat the animals they breed and once these animals drown, the father teaches Hushpuppy how to catch fish with her bare hands. Once these fish also die because of pollution, the father warns Hushpuppy not to accept food she is given at the shelter and it is after this refusal of welfare that Hushpuppy goes on somewhat of a magical journey, from which she returns with fried alligator meat, like her mother used to make, and feeds it to her dying father, having proclaimed that she's "gotta take care of [her] own." The ability to provide food becomes a means of asserting one's independence through the rejection of aid, and this ability is portrayed as an individual skill divorced from all material concerns.

Furthermore, by portraying sixyearold Hushpuppy as the provider, Beasts of the Southern Wild rejects even the notion of a child's dependency on the caregiver, promoting the view of independency as an inherent individual virtue. Unlike in Beast of the Southern Wild, in The Florida Project ' 'dependent' children serve as a constant reminder that caring for others is a central part of everyday life" (Hays 85), and sustenance as a form of care features prominently throughout the film. However, unlike in Beasts of the Southern Wild, the diet of characters in The Florida Project is shown to be informed primarily by economic concerns. Even though Halley and her daughter Moonee go to a welfare center, food stamps are never discussed as an option and we never see any of the characters relying on any form of public relief when it comes to food. However, the film does take us through a number of alternative solutions to the problem of sustenance: a friend of Halley's who lives at the same motel supplies her and Moonee, as well as her own son Scooty, with free waffles from the restaurant where she works. Other than on this informal form of relief, Halley and Moonee, as well as other motel residents, rely on another private source of aid: a Christian organization which visits the motel and hands out packages of (old) food, which Moonee and other children accept like a treat. The quality of food available to the poor is further discussed as we witness a series of junk food meals - Moonee and Halley live on waffles, pizza and Cheesies - but the reasons behind that kind of a diet are explicitly elaborated: Halley says she "make[s] some things, but Lunchables are like, a dollar." Similarly, she explains to Moonee that they cannot get pepperoni pizza because "pepperoni costs money." Instead of resorting to the 
narrative which would frame Moonee and Halley's diet as a product of the mother's irresponsibility and laziness, The Florida Project lays bare the material concerns which inform their lives outside both wage labor and welfare, thus subverting not only the discourse of dependency, but also the idea that the situation of wageless life can be explained in terms of personal responsibility and individual choices.

The issue of housing is treated similarly to the issue of food. Both films portray the characters' homes as "spaces of exclusion," exploring "the role of territorial stigmatization in the production of marginality." (Hancock and Mooney 107) However, whereas Beasts of the Southern Wild celebrates the Bathtub as nature, eliding the fact that it has been socially produced through the construction of the levee from its narrative, the conditions which informed the construction of the Magic Castle as the setting for The Florida Project are continually laid bare through visual references to Disneyland and a constant mention of tourists, for whom the motels along the Seven Dwarves Lane were originally built. As they do with food, characters in Beasts of the Southern Wild refuse being taken to a shelter, privileging the notion of a home over the idea of safe housing, which allows the film to romanticize their living conditions and the disaster with which they are faced as products of their choice. This portrayal of the Bathtub residents facing the flood resonates with conservative post-Katrina ${ }^{8]}$ commentary, which insisted that it was "not a lack of resources, private transportation, or out-of-town support systems that placed some of the most-needy New Orleans residents in the storm's path" (Peck 706), but rather "New Orleans residents choosing to disregard evacuation orders in anticipation of beginning-of-the-month welfare checks" (Peck 706). Beasts of the Southern Wild is not only as determined in its disregard of the social and material factors which produce the territorial exclusion of the Bathtub residents, but it radically idealizes their stubborn individuality instead of portraying them as dependent on welfare, thus promoting the virtue of personal responsibility. On the other hand, The Florida Project focuses prominently on the material conditions of living, with a number of scenes revolving around discussions of rent and the work Halley has to do to meet it every week, as well as several sequences which juxtapose the magical names and bright colors of motels with the drab reality of the characters' everyday lives. Both the Bathtub and the Magic Castle are shown as places populated by the surplus population, which spends its days without regard for the rhythm of working life. However, while Hushpuppy's 
description of the Bathtub as the place that has "got more holidays than the whole rest of the world" serves "to transform precarity into a moral failure, worklessness into laziness and social immobility and disconnection into an individual failure to strive and aspire" (Jensen 4), Halley's efforts to cover the ridiculously high three-hundred-dollars-a-week rent - which is her only choice since occasional work she finds in the informal sector does not allow her to save enough for a month's rent and security deposit needed to rent an apartment - elaborate on the conditions of wagelessness as a state of structural exclusion.

This is possible because, unlike Beasts of the Southern Wild, which seems to be completely divorced not only from the idea of work, but also from the imperative to earn a living, the plot of The Florida Project is driven by that very imperative in the context which is defined by a crisis of welfare due to a "transition to workfare [which] has made it possible to reassert in dramatic fashion the imperative of wage labor as a requisite of full membership in the civic community." (Wacquant 98) Since Beasts of the Southern Wild relies on the ideologemes of "a political culture dominated by the axioms of liberal political economy, it [is] not possible to conceptualize worklessness as a systemic and impersonal phenomenon" (Walters 151-52). On the other hand, at the beginning of The Florida Project, Halley detects a lag between the regulatory requirements of workfare and her lived experience due to a structural lack of work for unskilled labor in the formal economy. She is shown speaking to a social worker who tells her that the fact she has lost her job as a dancer because she refused to have sex with a client is "gonna affect [her] TANF" and asks her to "make a concerted effort to put in 30 hours." Despite her active effort, which she describes as having already applied "at every shithole up and down the strip" and asked her friend who works at a restaurant for help, Halley is unable to find work. This is when she turns to the informal sector: first we follow her as she sells perfume on hotel parking lots and then as she turns to sex work. It is only when her former friend informs the social services about this that the state, in the form of the social workers who come to take Moonee to a foster family, positively intervenes for the first time. Unlike the delinquent "welfare queen," Halley has not been the subject of constant surveillance, intended to ensure correct behavior, and her punishment is not strictly disciplinary in the sense of training her as an individual. Furthermore, even though she was a teenage mother, Halley is not framed like a "welfare queen" because there are quite simply no welfare funds she could depend 
on. So, as Astone correctly predicted, what happened with the introduction of PRWORA was not the eradication of "illegitimate" teen pregnancies and single motherhood as undesirable phenomena, but rather a transformation in the way these phenomena are dealt with, as well as the cost of dealing with them. The state is shown to be taking the same stance towards the population in the Bathtub. If punitive policies are significantly marked by "the recovered or renewed capacity of the state to bend so-called problem populations and territories to the common norm" (Wacquant 1), how could the Bathtub even happen? Instead of the constant surveillance of the delinquents failing to comply to the norm of wage labor and relying on welfare instead, we encounter the figure of the surplus population which believes it is invisible to the state and proclaims its independence, while the fact that there is nothing for it to depend on is elided from the narrative.

\section{Conclusion}

Understanding these films as cultural articulations of the conditions of wageless life at a specific historical moment affords us an opportunity not only to explore the departure from the figure of the "welfare queen" in the light of changes in the US welfare system, but also to consider the role of popular culture in negotiating such social changes. Observing the absence of the figure of the "welfare queen" as the privileged site at which anxieties related to welfare are organized, and linking this change to the changes in the US welfare system introduced by the 1996 Personal Responsibility and Work Opportunity Reconciliation Act, has allowed us to understand the shift from the figure of the "welfare queen" to the figure of the "surplus population" as a development parallel to the emergence of apparatuses typical of neoliberal governmentality. Since this newly emergent regime can seemingly no longer find an adequate cultural correlative in the figure of the "welfare queen," our aim was to analyze how contemporary films negotiate the conditions of wageless life after the neoliberal transformations of the welfare system. Looking at Beasts of the Southern Wild and The Florida Project as illustrative of a broader representational trend emerging in contemporary American film, our aim was to examine the role of popular culture in negotiating social changes by exploring the ways in which the two films negotiate dominant discourses of personal responsibility and work opportunity through the newly emergent figure of the "surplus population." The two films no longer frame the situation of wageless life by relying on the discourse 
of dependency - belying the fact that there is quite simply no longer anything to depend on - and both introduce the figure of the "surplus population." However, their portrayals of the conditions of contemporary wageless life differ significantly. Whereas Beasts of the Southern Wild romanticizes wageless life as a realm of freedom with Hushpuppy as an individual who achieves independence through a refusal of welfare and a celebration of personal responsibility, The Florida Project lays bare the material concerns which inform the lives of its protagonists outside both wage labor and welfare, thus subverting not only both the welfare-to-work narrative and the discourse of dependency, but also the idea that the situation of wageless life can be framed in terms of personal responsibility and individual choices.

\section{Works Cited}

Abramovitz, Mimi. Regulating the Lives of Women: Social Welfare Policy from Colonial Times to the Present. South End, 1988.

Astone, Nan Marie, and Jerry Watts. "The End of Work and the End of Welfare." Contemporary Sociology, vol. 26 , no. 4, 1997, pp. 409-15.

Beasts of the Southern Wild. Directed by Benh Zeitlin, Cinereach, 2012.

Bertram, Eva. The Workfare State: Public Assistance Politics from the New Deal to the New Democrats. University of Pennsylvania Press, 2015.

Dean, Mitchell. "Foucault Must Not Be Defended." History and Theory, vol. 54, 2015, pp. 389-403. Denning, Michael. "Wageless Life." New Left Review, vol. 66, November-December 2010, pp. 79-97.

Foucault, Michel. Discipline and Punish: The Birth of the Prison. 2nd ed., translated by Alan Sheridan, Vintage Books, 1995.

Foucault, Michel. Security, Territory, Population: Lectures at the College de France, 1977-1978. Translated by Graham Burchell, Palgrave Macmillan, 2007.

Foucault, Michel. Society Must Be Defended. Lectures at the College de France 1975-76. Translated by David Macey, Picador, 2003. 
Fraser, Nancy, and Linda Gordon. "A Genealogy of Dependency: Tracing a Keyword of the U.S. Welfare State." Signs, vol. 19, no. 3, 1994, pp. 309-36.

Gordon, Linda. Pitied but not Entitled: Single Mothers and the History of Welfare: 1890-1935. Harvard University Press, 1994.

Hancock, Ange-Marie. "Contemporary Welfare Reform and the Public Identity of the 'Welfare Queen'." Race, Gender \& Class, vol. 10, no. 1, 2003, pp. 31-59.

Hancock, Lynn, and Gerry Mooney. "Beyond the Penal State: Advanced Marginality, Social Policy and Anti-Welfarism." Criminalisation and Advanced Marginality: Critically Exploring the Work of Loïc Wacquant, edited by Squires, Peter, and John Lea, Policy Press, 2012, pp. 107-28.

Hays, Sharon. Flat Broke with Children: Women in the Age of Welfare Reform. Oxford University Press, 2003.

Jensen, Tracey. "Welfare Commonsense, Poverty Porn and Doxosophy." Sociological Research Online, vol. 19, no. 3, 2014, pp. 1-7. Accessed 20 July 2018.

Laslett, Barbara, and Johanna Brenner. "Gender and Social Reproduction: Historical Perspectives." Annual Review of Sociology, vol. 15, 1989, pp. 381-404.

Marx, Karl. Capital. A Critique of Political Economy. Volume I. Harmondsworth, 1976.

Peck, Jamie. "Liberating the City: Between New York and New Orleans." Urban Geography, vol. 27 , no. 8, 2006, pp. 681-713.

Shiel, Mark. "Cinema and the City in History and Theory." Cinema and the City: Film and Urban Societies in a Global Context, edited by Shiel, Mark, and Tony Fitzmaurice, Blackwell Publishers, 2001, pp. 1-19.

Soss, Joe, Rochard C. Fording, and Sanford F. Schram. Disciplining the Poor: Neoliberal Paternalism and the Persistent Power of Race. University of Chicago Press, 2011.

The Florida Project. Directed by Sean Baker, Cre Film, Freestyle Picture Company et al., 2017.

Walters, William. Unemployment and Government: Genealogies of the Social. Cambridge University Press, 2000. 
Wacquant, Loïc. Punishing the Poor: The Neoliberal Government of Social Insecurity. Duke University Press, 2009.

Weeks, Kathi. The Problem with Work: Feminism, Marxism, Antiwork Politics, and Postwork Imaginaries. Duke University Press, 2011.

“'Welfare Queen' Becomes Issue in Reagan Campaign.” The New York Times, 15 February 1976, https://www.nytimes.com/1976/02/15/archives/welfare-queen-becomes-issue-in-reagan-campaignhitting-a-nerve-now.html. Accessed 2 August 2018.

Williams, Raymond. Marxism and Literature. Oxford University Press, 1977. 
[1] Foucault's work is engaged here not as a set of definitive explanations of concrete phenomena observed through empirical analysis, but rather as "a perspective on how to investigate diverse practices and regimes of government" (Dean 400), which has proved to be analytically productive in discussions of forms of domination and relations of power. Furthermore, this paper does not rely on Foucault's work as an anticipation of concrete changes in the forms of government and economy which have occurred over the past thirty years.

[2] The cultural life of this figure began even somewhat earlier, during the 1976 presidential campaign, as Reagan repeatedly referred to a welfare recipient from Chicago, whom the media immediately labeled as a "welfare queen" due to the future president's exaggerated portrayal of her abuse of the system. At the time, the New York Times reported that Reagan described the woman, who has been identified as Linda Taylor, in the following way: "She has 80 names, 30 addresses, 12 Social Security cards and is collecting veterans' benefits on four non-existing deceased husbands.' He added: 'And she's collecting Social Security on her cards. She's got Medicaid, getting food stamps and she is collecting welfare under each of her names. Her tax-free cash income alone is over $\$ 150,000$.'” (“Welfare Queen”') A number of articles have tried to ascertain the exact extent of Taylor's crimes, but the figure of the "welfare queen" has long since been divorced from any one individual and assumed a cultural life of its own.

[3] The measures provided by the Act included the demand that TANF recipients apply for 40 jobs in 30 days, attend job readiness and life skills classes divorced from the needs of unskilled jobs available to them, or that, should they fail to find employment, they take on Community Work Experience, doing unskilled work for the state, county, city, or other non-profit agency without pay (cf. Hays 39-40). No reason or incentive was offered which would explain "how and why businesses would suddenly rush to employ en masse a sorely underqualified population ... that is moreover stigmatized when the market was already awash with cheap labor." (Wacquant 86)

[4] Not only did most work "part time, most lacked medical and social insurance, and they earned an average of seven dollars an hour - keeping them well below the federal poverty line" (Wacquant 95). Furthermore, the "situation of ex-recipients who had found full-time work was scarcely less 
precarious, since 30 percent did not earn an income sufficient to cover their rent [and] 46 percent worried about getting enough food" (Wacquant 96).

[5] Of course, in offering only this brief discussion of the PRWORA, we must be careful not to exaggerate its intentionality and coherence. Nevertheless, the aim of this overview is to provide a basic outline necessary for the argument which will be developed later.

[6] As Hays notes with regard to the (un)employment rates of former welfare recipients postPRWORA: "This 60/40 split of employed versus unemployed former welfare recipients has remained fairly steady from 1998 to 2002 . This means that every time someone in the nonworking 40-percent category finds a job, some family in the working 6o-percent category loses their job."

[7] It should be noted that the previous discussion of biopolitics and its mechanisms does not imply a clear historical succession of different mechanisms of power, with one mechanism replacing another in a clearly identifiable inaugural event. Instead, what is suggested here is a co-existence of multiple mechanisms, which complicates straightforward accounts of the US welfare as a disciplinary mechanism based on punitive techniques, without arguing against them.

[8] Both the setting and the events portrayed in Beasts of the Southern Wild are significantly informed by the hurricane which hit New Orleans in 2005.

\section{cc) ()ㅇ}

Creative Commons Attribution-NonCommercial-NoDerivatives 4.0 International License 